\title{
Article
}

\section{Remedying Displacement in Frozen Conflicts: Lessons from the Case of Cyprus}

\author{
Hadjigeorgiou, Nasia
}

Available at http://clok.uclan.ac.uk/15071/

Hadjigeorgiou, Nasia ORCID: 0000-0002-7324-9689 (2016) Remedying

Displacement in Frozen Conflicts: Lessons from the Case of Cyprus.

Cambridge Yearbook of European Legal Studies, 18 . pp. 152-175. ISSN 15288870

It is advisable to refer to the publisher's version if you intend to cite from the work.

http://dx.doi.org/10.1017/cel.2016.6

For more information about UCLan's research in this area go to http://www.uclan.ac.uk/researchgroups/ and search for < name of research Group>.

For information about Research generally at UCLan please go to http://www.uclan.ac.uk/research/

All outputs in CLoK are protected by Intellectual Property Rights law, including Copyright law. Copyright, IPR and Moral Rights for the works on this site are retained by the individual authors and/or other copyright owners. Terms and conditions for use of this material are defined in the policies page.

\section{CLoK}

Central Lancashire online Knowledge www.clok.uclan.ac.uk

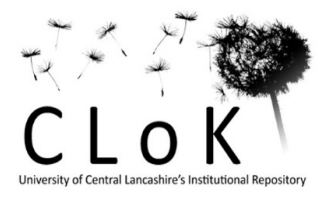




\title{
REMEDYING DISPLACEMENT IN FROZEN CONFLICTS: LESSONS FROM THE CASE OF CYPRUS
}

\author{
NASIA HADJIGEORGIOU*
}

\begin{abstract}
This article examines the jurisprudence of the European Court of Human Rights, in order to assess the effectiveness of the remedies provided and procedures followed by the Immovable Property Commission (henceforth, IPC), a mechanism that was established by Turkey in order to remedy displaced Greek Cypriots. It recommends changes for the improvement of the IPC and argues that with their adoption, the Commission could act as a blueprint for the establishment of similar remedying bodies in other frozen conflicts as well. Such institutions are not only important in terms of states' compliance with their human rights obligations, but can also contribute to the resolution of the underlying conflict itself.
\end{abstract}

Keywords: Forced displacement, frozen conflicts, effective remedies, Cyprus.

\section{INTRODUCTION}

Over the last decades, the European Court of Human Rights (henceforth, ECtHR or Court) has adjudicated a number of cases where applicants, who have been forcibly displaced from their properties as a result of violent conflict, seek a remedy for the violation of their rights. ${ }^{1}$ This jurisprudence has been particularly influential in those societies which, years after the ceasefire that ended the violence, are still divided by 'frozen conflicts' not yet resolved through comprehensive peace agreements. Several such frozen conflicts exist in Europe and so far, the Court has dealt with cases relating to forced displacement in two of them - Cyprus and Nagorno-Karabakh. The ECtHR's consistent response in these cases has been that the respondent state has an obligation to remedy displaced people, especially when the negotiations for the settlement of the conflict have been ongoing, yet remain unfruitful, for years. ${ }^{2}$ These remedies, it was accepted in Demopoulos v. Turkey ${ }^{3}$ and subsequently reiterated in Chiragov v. Armenia ${ }^{4}$ and Sargysian v. Azerbaijan, should be provided to the displaced population by a domestic institution with a special mandate to act accordingly.

\footnotetext{
* University of Central Lancashire, Cyprus Campus (ahadjigeorgiou@uclan.ac.uk). I would like to thank Dr Nikolas Kyriakou, Dr Aris Constantinides, Dr Arman Sarvarian, Dr Stephanie Laulhe Shaelou and the anonymous reviewer for their comments. Any remaining errors are my own.

${ }^{1}$ T Allen and B Douglas, 'Closing the Door on Restitution: The European Court of Human Rights' in A Buyse and M Hamilton (eds), Transitional Jurisprudence and the ECHR: Justice, Politics and Rights (CUP, 2011). The Registrar of the ECtHR noted in 2014 that while the Court 'cannot settle war-like conflicts between states', it has been called to deal with approximately 3,000 such cases; many of these cases concern property disputes. (Steering Committee for Human Rights, Committee of Experts on the Reform of the Court, 'Presentation to the $3^{\text {rd }}$ Meeting by the Registrar of the European Court of Human Rights' (Strasbourg: Council of Europe, 2014), available at http://www.coe.int/t/dghl/standardsetting/cddh/reformechr/GT-GDR-F/GT-GDR-F(2014)21-Speech-ErikFribergh-24092014\%20(2).pdf [last accessed 31 May 2016].

${ }^{2}$ See for example, Sargsyan v. Azerbaijan (Application no. 40167/06) (2015), paras 236-237.

${ }^{3}$ Demopoulos and Others $v$. Turkey (Application no. 46113/99) (2010) 50 E.H.R.R. SE14.

${ }^{4}$ Chiragov and Others v. Armenia (Application no. 13216/05) (2015).
} 
In light of the numerous examples of forced displacement as a result of frozen conflicts, and the possibility that it can act as a blueprint for them, this article examines the remedies provided and procedures followed by the Immovable Property Commission (henceforth, IPC or Commission) in Cyprus. It argues that any institution established to remedy forced displacement should aim to achieve two objectives: first, it should comply with human rights and second, it should work towards the unfreezing of the conflict by building trust between its different parties. Drawing lessons from the experiences of the IPC, the ECtHR's case law and other key international policy documents, the article seeks to provide guidelines for the establishment and operation of such remedying bodies. These guidelines could be useful, particularly to the governments of Armenia and Azerbaijan that are currently under an obligation to comply with the ECtHR's Chiragov/Sargysian judgments, but also to other countries affected by frozen conflicts in Europe and elsewhere. At the same time, this analysis remains relevant to Cyprus, whose leaders are optimistic about the outcome of the ongoing negotiations for a comprehensive peace settlement. ${ }^{5}$ If the negotiations are successful, the experiences of the IPC could provide useful insights for the establishment of a new body that, once and for all, will afford a remedy to everyone who has been displaced by the conflict on the island.

\section{FROZEN CONFLICTS AND FORCED DISPLACEMENT IN EUROPE}

Frozen conflicts are characterised by the eruption of violence between two or more groups, followed by a ceasefire agreement which, although it results in the stopping of the altercations, does not permanently resolve the disagreement between the previously warring parties. Thus, although the situation is stable, sometimes even safe, the unresolved conflict lingers and the unsatisfactory status quo is maintained. The parties might refuse to acknowledge each other or conversely, they might participate in perpetual, yet ineffective, negotiations; in both cases however, the zero-sum nature of their disagreement makes them unable to reach a settlement for their common future. Such frozen conflicts in Europe include Cyprus, Nagorno-Karabakh, Abkhazia, South Ossetia and Transnistria, with political analysts being concerned that Eastern Ukraine is also heading in the same direction. ${ }^{6}$

These frozen conflicts share important similarities that make a comparison between them valuable. The first such similarity is that they have all resulted, to different extents, in instances of forced displacement. Approximately 45,000 Turkish Cypriots (henceforth, TC) and 165,000 Greek Cypriots (hereafter, GC) have been displaced during the conflict on the island. ${ }^{7}$ Similarly, since the beginning of the 1990s, there have been 240,000 displaced persons in Abkhazia, ${ }^{8} 800,000$ Azeri refugees in Nagorno-Karabakh, ${ }^{9}$ and 50,000 in Transnistria. ${ }^{10}$ Moreover, the 2008 Russian-Georgian war resulted in approximately 120,000 refugees from

\footnotetext{
${ }^{5}$ United Nations Peacekeeping Force in Cyprus, 'Joint Statement by the Turkish Cypriot Leader Mr. Mustafa Akinci and Greek Cypriot Leader Mr. Nicos Anastasiades', available at https://unficyp.unmissions.org/jointstatement-turkish-cypriot-leader-mr-mustafa-akınc1-and-greek-cypriot-leader-mr-nicos [last accessed 17 June 2016].

${ }^{6}$ International Crisis Group (henceforth, ICG), 'Russia and the Separatists in Eastern Ukraine' (Kiev/Brussels: ICG, 2016), p 1.

${ }^{7}$ Global IDP Database, 'Profile of Internal Displacement: Cyprus' (Geneva: Norwegian Refugee Council/ Global IDP Project, 2003), p 6, citing estimates of the UN Peacekeeping Force in Cyprus.

${ }^{8}$ Global IDP Database, 'Profile of Internal Displacement: Georgia' (Gevena: Norwegian Refugee Council/Global IDP Project, 2005), p 6, citing estimates of the UN Office for the Coordination of Humanitarian Affairs.

${ }^{9}$ See note 4 above, para 25 .

${ }^{10} \mathrm{Z}$ Brunarska and A Weinar, 'Asylum Seekers, Refugees and IDPs in the EaP Countries: Recognition, Social Protection and Integration - An Overview' (CARIM-East Research Report 2013/45), p 5.
} 
South Ossetia, ${ }^{11}$ with some 20,000 ethnic Georgians still remaining unable to return to their houses. ${ }^{12}$ While forced displacement is a characteristic of violent contexts more generally, frozen conflicts face additional challenges to the usual ones. The most important such challenge concerns the passage of time and the fact that in the years that passed since the displacement, other people might have moved in the properties in question. ${ }^{13}$ The longer the period since the war, the more necessary it becomes to balance any interests the secondary occupiers might have acquired with those of the original property owners. ${ }^{14}$ Yet, the complexity of this balancing exercise is not reflected in the seminal UN Principles on Housing and Property Restitution for Refugees and Displaced Persons (henceforth, the Pinheiro Principles), which merely declare that 'All refugees and displaced persons have the right to have restored to them any housing, land and/or property of which they were arbitrarily or unlawfully deprived.' 15 Since restitution returns the displaced population to its original position to the greatest possible extent, it is only right that it is the international community's preferred remedy. While however, its use is uncontroversial in conflicts that have lasted for a relatively short period of time, it creates difficulties of principle and application in frozen conflicts. ${ }^{16}$ Examining how this balance has been struck and displacement has been remedied in one frozen conflict, can provide useful lessons about how similar questions can be addressed in another.

The second similarity between such conflicts concerns the fact that they all tend to be characterised by a lack of trust between the different groups of the population. Although frozen conflicts usually result in relatively stable conditions on the ground, uncertainty about how they will develop in the future contributes to feelings of insecurity among the public. ${ }^{17}$ In turn, this often translates to a lack of trust both towards the politicians that are negotiating the settlement and between the populations of the different parties to the conflict. ${ }^{18}$ It is therefore important that if a remedying mechanism is established in such societies, especially when it is concerned with such a sensitive issue as forced displacement, it takes steps to improve trust levels between the politicians and the population and also among the people themselves. However, while 'restoring public trust in national institutions of governance' ${ }^{19}$ is among the key objectives of transitional justice, and although post-conflict societies often establish institutions with this mandate, trust-building has received far less attention in contexts of frozen

\footnotetext{
${ }^{11}$ ICG, 'Russia v. Georgia: The Fallout' (Tbilisi/Brussels: ICG, 2008), p 3.

12 ICG, 'South Ossetia: The Burden of Recognition' (Tskhinvali/Tbilisi/Istanbul/Moscow/Brussels: ICG, 2010), $\mathrm{pi}$.

${ }^{13}$ A Smit, The Property Rights of Refugees and Internally Displaced Persons: Beyond Restitution (Routledge, 2012), p 170.

${ }^{14}$ Laura Matson, 'Competing Land Rights, Legal Redress, and Political Settlement in Cyprus' (2012) 31 Law and Inequality 199.

15 Sub-Commission on the Promotion and Protection of Human Rights, 'Principles on Housing and Property Restitution for Refugees and Displaced Persons' (Geneva: UN, 2005), Principle 2.1.

${ }^{16}$ See note 13 above.

${ }^{17}$ Despite the stable status quo in Cyprus, more than $70 \%$ of GC and TC believe that security should be the 'highest priority item' during the peace negotiations. (A Lordos and E Kaymak, 'Public Opinion and the Property Issue: Quantitative Findings' (Cyprus: Interpeace, 2010).)

${ }^{18}$ For an illustration of this in Nagorno-Karabakh, see ICG, 'Nagorno-Karabakh: Getting to a Breakthrough' (Baku/Yerevan/Tbilisi/Brussels: ICG, 2009), p 1 and 8. Conversely for the case of Cyprus, Matson (note 14 above, $\mathrm{p} 230$ ) argues that GC and TC enjoy greater levels of trust and do not seem to be divided by the 'ancient hatreds' that characterise other such societies. With respect, the never-ending, unfruitful negotiations, the nationalist rhetoric of both GC and TC politicians and the overwhelming rejection of the UN-sponsored Annan Plan (see not 132 below) by the GC community, suggest otherwise.

${ }^{19}$ UN Secretary-General, 'The Rule of Law and Transitional Justice in Conflict and Post-conflict Societies' (New York: UN, 2004), para 1.
} 
conflicts. ${ }^{20}$ This is puzzling because trust-building is as important to a society that is negotiating a peace agreement, as it is to one that has already completed the negotiations and is in the process of building the common institutions that have been agreed. Peacebuilders usually focus on transitional justice mechanisms after a comprehensive peace settlement has been reached, but there is nothing that prevents parties from adopting such mechanisms before, or even in order to aid, the successful completion of the negotiation process. This was confirmed by Judge Ziemele in Sargsyan, when he argued that remedying the displaced people could 'be a way of moving towards finding a solution to the conflict'. 21

Thus, and although it has rarely been perceived as such, the IPC should be seen and evaluated as a rather unique example of transitional justice mechanisms. ${ }^{22}$ If it is successful, such a mechanism could contribute to the unfreezing of the conflict in two ways. On the one hand, it could make a direct contribution to conflict settlement by protecting the human rights of the displaced population; in turn, this could put the victims in their original position as much as possible and allow them to eventually leave the conflict behind them. ${ }^{23}$ On the other, it could make symbolic contributions to the resolution of the conflict by sending messages of reconciliation to the population at large. ${ }^{24}$ When responding to forced displacement in frozen conflicts therefore, the objective should not only be to provide effective remedies in the legalistic and technical sense of the word, but also to address the root of the problem and ensure that these contribute to the betterment of inter-ethnic relations among the people of the divided society. As Shelton put it, in cases of armed conflict 'reparations are often a matter of compromise and look to the future as much as to the past'. ${ }^{25}$

The final common characteristic of frozen conflicts is that with the passage of time, the political and legal context in which they are negotiated, changes. The institution that has altered in the most dynamic way this context in Europe is the ECtHR. ${ }^{26}$ Of Europe's frozen conflicts, two Cyprus and Nagorno-Karabakh - have resulted in decisions of the Court relating to forced displacement. The (GC) cases against Turkey, and in particular Cyprus v. Turkey and Loizidou v. Turkey, ${ }^{27}$ are well known among the academic community. ${ }^{28}$ In the admissibility decision of Loizidou, the Court reached two findings with significant implications for frozen conflicts: ${ }^{29}$ first, that Turkey was in effective control over the north of Cyprus and therefore responsible

\footnotetext{
${ }^{20}$ Although some confidence-building measures have been adopted in Cyprus, these have received a lot less attention by the media and the peacebuilders themselves, than the formal negotiations. (M Hadjipavlou and B Kanol, 'Cumulative Impact Case Study: The Impact of Peacebuilding Work on the Cyprus Conflict' (Nicosia: CDA Collaborative Learning Projects, 2008).)

${ }^{21}$ See note 2 above, Concurring Opinion of Judge Ziemele, para 7. See also, Council of Europe Parliamentary Assembly, 'Europe's Forgotten People: Protecting the Human Rights of Long-term Displaced Persons' (Recommendation 1877 (2009)), which recommends in para 10 that in cases of frozen conflicts, '[t]ransitional justice measures have to be established to address wrongs suffered (including arbitrary displacement)'.

${ }^{22}$ N Skoutaris, 'Building Transitional Justice Mechanisms without a Peace Settlement: A Critical Appraisal of Recent Case Law of the Strasbourg Court on the Cyprus Issue' (2010) 35 European Law Review 720.

${ }^{23}$ United Nations High Commissioner for Refugees, The State of the World's Refugees: A Humanitarian Agenda (OUP, 1997), p 162.

${ }^{24}$ D Shelton, Remedies in International Human Rights Law (OUP, 2006, 2nd edn.), pp 16-17 and 150.

${ }^{25}$ Ibid., p 430.

${ }^{26}$ See P Leach, 'Thawing the Frozen Conflict? The European Court's Nagorno-Karabakh Judgments' (EJIL blog, posted on 6 July 2015) available at http://www.ejiltalk.org/thawing-the-frozen-conflict-the-european-courtsnagorno-karabakh-judgments/ [last accessed 31 May 2016], arguing that the Court's recent case law is showing its greater willingness to become involved in such frozen conflicts.

${ }^{27}$ Loizidou v. Turkey (Application no. 15318/89) (1997) 23 E.H.R.R. 513 (Merits).

${ }^{28}$ The Cypriot conflict has also given rise to TC applications to the ECtHR. For an analysis of these, see $\mathrm{N}$ Hadjigeorgiou, 'Case Note on Kazali and Others v. Cyprus' (2013) 2 Cyprus Human Rights Law Review 103.

${ }^{29}$ Loizidou v. Turkey (Application no. 15318/89) (1995) 20 E.H.R.R. 99 (Preliminary Objections).
} 
for any violations that are taking place there; the self-declaration of the 'Turkish Republic of Northern Cyprus' (hereafter, 'TRNC') as an independent state could not shield Turkey from its human rights obligations. ${ }^{30}$ Second, even though the displacement of the applicant had taken place in 1974, there was a continuing interference with her right to use her property that persisted (and was renewed every day) until the violation had been remedied. ${ }^{31}$ Both of these conclusions have been reiterated in Chiragov, in which the Court held that Armenia was responsible for violations of the right to property of displaced people in Nagorno-Karabakh because, like Turkey in northern Cyprus, it has been in effective control of the region. ${ }^{32}$

At the merits stage of Loizidou, the Court held that the prevention of the applicant to use her property by the Turkish military constituted a violation of the right to property under Article 1 of Protocol No. 1 (henceforth, Article 1-1) of the European Convention. This created an obligation on Turkey to remedy the applicant, not for the loss of the property itself, but for her inability to access and use it. Thus, even after she had been remedied, the applicant remained the owner of the property, an important consideration in light of the developments following the establishment of the IPC. The Court confirmed its Loizidou findings in Cyprus v. Turkey, where before finding a violation of Article 1-1, it held that it was not necessary to exhaust domestic remedies, thus granting the applicant direct access to it, because the practices of the 'TRNC' were discriminatory against GC and, therefore, ineffective. ${ }^{33}$ Loizidou's findings were endorsed and expanded in the numerous cases with identical facts that followed, such as Demades v. Turkey, in which the Court held that the prevention of the applicant to access his house did not only constitute a violation of the right to property, but also of the right to home, as protected under Article 8 of the European Convention. ${ }^{34}$

The Loizidou line of cases changed the context in which the Cypriot negotiations were taking place since they provided, for the first time, an authority for the view that leaving the displaced population without any remedy at all was not an option. Nevertheless, it is the case of XenidesArestis v. Turkey and the admissibility decision of Demopoulos $v$. Turkey that most vividly show the dynamic effects of the ECtHR jurisprudence. ${ }^{35}$ In Xenides-Arestis, Turkey argued that a newly created mechanism, the IPC, provided an effective remedy that the applicants should exhaust before having access to the ECtHR. The Court accepted the argument in principle, but ultimately held that the composition of the IPC and the remedies it was providing at the time, were in need of further improvement. It was 5 years later in Demopoulos that the ECtHR finally held that the amended IPC Law and the Commission it gave rise to provided effective remedies to GC applicants. ${ }^{36}$ In this case, the Court also went back to some of its previous decisions and held that the applicant's complaint about a violation of Article 8 was manifestly ill-founded because the passage of time had weakened her links to her home and,

\footnotetext{
${ }^{30}$ Ibid., para 63.

${ }^{31}$ See note 27 above, para 41.

${ }^{32}$ See note 4 above, para 186. Conversely, Azerbaijan's responsibility was engaged because the displacement had taken place in its internationally recognised territory, where it has an obligation to take positive actions to protect human rights. While Azerbaijan restricted access to Nagorno-Karabakh for legitimate reasons, it still violated the right to property because it did not compensate the displaced population in any way. (See note 2 above, paras 223226 and 234.)

${ }^{33}$ Cyprus v. Turkey (Application no. 25781/94) (2002) 35 E.H.R.R. 30, paras 99, 172 and 184.

${ }^{34}$ Demades v. Turkey (Application no. 16219/90) (2003).

${ }^{35}$ Xenides-Arestis v. Turkey (Application no. 46347/99) (2007) 44 E.H.R.R. SE13.

${ }^{36}$ See note 3 above, para 90.
} 
as a result, 'the holding of a title [... was] emptied of any practical consequences' ${ }^{37}$ Importantly, this aspect of the ECtHR's decision has impacted on the provision of remedies, in particular restitution and compensation, by the IPC.

In Demopoulos, the applicant and the Cypriot government that supported his claim, repeated the arguments that the Court had already dismissed in Xenides-Arestis, namely that the IPC could not, as a matter of principle, provide an effective remedy because it was the product of an illegal invasion and it was established by an entity that was not recognised in international law. Both arguments were again rejected by the Court, which declared that the IPC was established, not by the 'TRNC', but by Turkey. ${ }^{38}$ This is a legaly persuasive argument and a convenient way of sidestepping the difficult question of the legitimacy and legality of both the 'TRNC' and the IPC. Nevertheless, disagreements of principle cannot be completely separated from questions of practical effectiveness, especially because they can influence the provision of the remedies of restitution and exchange. Ironing this crease out, the Court held that the mechanisms provided by Turkey could not be by definition ineffective because that would mean that the applicants were not actually expecting the respondent state to remedy them in some way, which would render their resort to the ECtHR futile. ${ }^{39}$ Thus, Demopoulos has changed the context relating to forced displacement in Cyprus because since then, applicants have had to exhaust domestic remedies, and in particular apply to the IPC in order to obtain access to the ECtHR. Whether these domestic remedies are effective as a matter of practice, rather than principle, is not an argument that was seriously pursued by the applicants or that has been discussed by academics since then. ${ }^{40}$ It is this gap in the literature that the subsequent analysis seeks to address.

Before commencing on an assessment of the IPC, one final caveat must be made: the Commission is an organ that is clouded in secrecy, which creates difficulties if one's objective is to examine its practical effectiveness. Ideally, such an exercise would focus on the IPC's decisions and enforced rules of procedure. On the one hand, these would provide basic information, like the start and end date of a case, the type of remedy each applicant asked for and what s/he ultimately received. On the other, they would allow for an evaluation of the IPC's reasoning and shed light on its procedures. Nevertheless, no such decisions exist. So far, the Commission has finalised 935 applications, 913 of which have been completed through a friendly settlement process $;{ }^{41}$ for these cases, no evidence at all is made available. The specific remedies asked for and ultimately provided in each case are unknown, as are the start and end dates of the process. The remaining 22 cases have been completed through hearings, but here as well, the reasoning of the IPC - or any other information concerning the case - remains publically unavailable.

\footnotetext{
${ }^{37}$ Ibid., para 111. For a criticism of the Court's decision in relation to the right to home, see C Paraskeva and E Meleagrou, 'Homes from the Past: An Expiration Date for the Right to Respect for Home Under Article 8 of the European Convention on Human Rights' (2012-2013) VII Annaire International Des Droits De L'Homme 845.

${ }^{38}$ See note 3 above, para 95.

${ }^{39}$ Ibid., para 89.

40 The literature on Demopoulos has mostly dealt with the question of whether the IPC could provide effective remedies as a matter of principle, rather than practice. See, for example, E Katselli-Proukaki, 'The Right of Displaced Persons to Property and to Return Home after Demopoulos' (2014) 14 Human Rights Law Review 701; L Loucaides, 'Is the European Court of Human Rights Still a Principled Court of Human Rights after the Demopoulos Case?' (2011) 24 Leiden Journal of International Law 435.

41 Presidency of IPC, 'Monthly Bulletin, May 2016', (Nicosia: IPC, May 2016), available at http://www.tamk.gov.ct.tr/dokuman/istatistik_mayıs16ing.pdf [last accessed 31 May 2015].
} 
Thus, this article assesses the effectiveness of the IPC by relying on the few documents that are publically available and on a series of interviews that were conducted in Cyprus during the period of November 2014 - March 2015. Few applicants openly admit that they have gone to the IPC because those who do are labelled among many in the GC community as 'traitors', as collaborating with the 'enemy' and selling their patrimonial land for financial gain. ${ }^{42}$ Because of the difficulty in identifying individual applicants, the interviews focused on people that are involved in their professional capacity with the IPC. Such professionals were easier to identify and persuade to interview, while, as a result of their regular involvement with the Commission, they had a more all-round understanding of its strengths and limitations. Overall, 8 interviews were carried out: 3 with GC private lawyers, 3 with TC private lawyers, 1 with a TC land surveyor and 1 with a lawyer from the RoC's Attorney-General's office. ${ }^{43}$ Combined, the interviewees have represented approximately 700 out of the 6286 applications that have been submitted to the Commission to date, thus providing, through the recollection of their experiences, an accurate picture of the IPC's practices. ${ }^{44}$ The semi-structured interviews lasted between 1-2 hours each and all of them were given on condition of anonymity. The views of the participants are of course subjective and they cannot replace hard facts about the effectiveness of the IPC. However, on a surprising number of issues, the participants had very similar views of the Commission, thus making it possible to draw some preliminary conclusions about its effectiveness.

\section{AN ASSESSMENT OF THE REMEDIES PROVIDED BY THE IPC}

The IPC was created by Law 67/2005, which gives GC who were displaced from their properties in 1974, the opportunity to be remedied for the loss they suffered. ${ }^{45}$ In principle, applicants can choose from three types of remedies: payment of compensation for the loss of their property; its return (restitution); or the exchange of their property found in the north of the island, with a TC property of equal value in the south. ${ }^{46}$ Nevertheless, in practice, the first of the three is by far the most popular: of the 759 applicants that have been remedied so far, 746 have received compensation. ${ }^{47}$ If the applicant has been awarded one of the three remedies, he also becomes entitled to compensation for loss of use of that property from 1974 until today. ${ }^{48}$ It is however, impossible for an applicant to request only compensation for loss of use without also claiming compensation, exchange or restitution of the property itself. Bearing in mind that the applicants who originally resorted to the ECtHR were only demanding a remedy for the loss of use of their properties, GC perceive this provision of the law as unfair. They are arguing that in essence Turkey is giving with the one hand and taking with the other since one

\footnotetext{
${ }^{42}$ See, for example, comments from the RoC Minister of the Interior that if the applications to the IPC continue with the same pace, 'then we will solve the Cyprus problem on our own, in the worst possible way because there will be nothing left to negotiate (with regards to properties), nor to exchange. So, on our own, we will partition Cyprus. There can be no homeland without the land.' (author's translation, 'Statements of the Minister of the Interior' (16 June 2013), available at http://www.pio.gov.cy/moi/pio/pio.nsf/All/5BBD393E78B6C0F0C2257B8C0042802C?OpenDocument\&highli ght=16/06/2013 [last accessed 17 June 2016]).

${ }^{43}$ Attempts were made to hold an interview with an IPC member of staff as well, but these were unsuccessful.

${ }^{44}$ See note 41 above.

45 ('TRNC') Law No. 67/2005 ('Law for the Compensation, Exchange and Restitution of Immovable Properties which are within the scope of sub-paragraph (B) of paragraph 1 of Article 159 of the Constitution').

${ }^{46}$ Law 67/2005, Section 4(1).

${ }^{47}$ See note 41 above, p 5.

${ }^{48}$ Law 67/2005, Section 8.
} 
can only become remedied for loss of use if he is willing to give up the title of the property itself (in the vast number of cases in lieu of compensation).

In addition to this general criticism of the IPC, this section engages with the concerns that have been raised about each of the specific remedies and reaches three conclusions. First, despite the relatively low compensation amounts awarded by the Commission, this is unlikely to constitute a violation of the right to property. However, in order for this remedy to contribute to feelings of trust among previously warring parties, the Commission should justify its decisions and explain to the applicants the considerations that have affected the specific compensation amounts they received. Second, implementing the remedy of exchange results in confusion about who is entitled to what and seriously undermines the objective of building trust among the two communities. This suggests that when remedying bodies are being designed, close attention should be paid to the remedies that are made available to the applicants and the effects these can have, not only on the specific displaced person, but also on the population at large. Third, the strict requirements that the remedy of restitution is subject to, do not in themselves constitute a violation of the right to property. However, where the IPC interprets and applies them in such a way as to render the remedy completely unavailable, this can result in violations of both the right to property and fair trial. It is therefore necessary that remedying bodies take steps to ensure that they are interpreting the law accurately, rather than allowing political considerations to cloud their judgements.

\section{A. The remedy of compensation}

One of the most serious complaints against the IPC is that the compensation amount it offers to the applicants is so much lower than the market price that it does not qualify as an effective remedy at all. ${ }^{49}$ Assessing the accuracy of this complaint is difficult both because of lack of information and due to several disagreements of principle between the two sides. Every month, the IPC publishes information about the number of cases it has settled and the total compensation amount it has paid during that period. However, it does not disclose how much has been awarded for individual and identifiable pieces of land. Law 67/2005 provides that the compensation amount should be determined by taking into account four factors: the market value of the property in 1974; the loss of income and increase in the value of the property from then until the date of payment; whether the applicant is in possession of any TC property in the RoC-controlled areas; and whether s/he is receiving income from such a property. ${ }^{50}$ Nevertheless, these factors have not been elaborated on by the IPC, thus making it unclear, for example, whether an applicant who has lost his/her home and another who has lost a plot of land in the same village, should be compensated in the same way. Potentially, this weakness of the IPC could have been avoided, had the ECtHR adopted a more principled approach when dealing with the concept of the 'home' in Demopoulos.

The lack of guidance about the compensation applicants should expect can be problematic in light of the ECtHR's case law in relation to Article 1-1, which provides that the law in question must be adequately accessible and sufficiently precise. ${ }^{51}$ As a minimum requirement, it is necessary that applicants have an indication of the legal rules that apply to their case in order to foresee to a reasonable degree the consequences of their actions. ${ }^{52}$ This obligation is potentially frustrated here because, in most cases, applicants remain completely in the dark

\footnotetext{
${ }^{49}$ See note 3 above, para 121.

${ }^{50}$ Law 67/2005, Section 8(4).

${ }^{51}$ Sunday Times v. United Kingdom (Application no. 6538/74) (1979-80) 2 E.H.R.R. 245, para 49.

${ }^{52}$ Ibid.
} 
about the outcome of the remedying process, namely the amount of compensation they can expect to receive. Thus, in Hentrich $v$ France, the ECtHR found a law interfering with the applicant's property rights to be in violation of Article 1-1 because it 'operated arbitrarily and selectively and was scarcely foreseeable, and it was not attended by the basic procedural safeguards' ${ }^{53}$ Perhaps more problematic however, is the effect of this uncertainty in terms of how the IPC is perceived by the GC population. In particular, leaving the applicants in the dark about the compensation amount they will receive, risks disappointing them and making them feel that they have been cheated. While it is uncertain whether applicants actually experience such disappointment, the high percentage of applications that have been submitted to the IPC and then subsequently revoked before a final decision has been made, is a worrisome indication. ${ }^{54}$

In addition to the lack of information, assessing whether the compensation amount provided by the IPC is adequate becomes difficult due to several disagreements of principle. More specifically, the decision of whether the compensation amount falls far below the market price depends on what one understands by the 'market' in the first place. ${ }^{55} \mathrm{GC}$ argue that in order for the applicants to be adequately remedied for their loss and return to their original position as much as possible, they must be compensated as if the Turkish invasion had never taken place. They further submit that the market prices in the north today do not really reflect the properties' true value because two external factors keep them artificially low. First, the fleeing of GC from the north due to the 1974 invasion has meant that the demand for (and therefore the market price of) properties has gone down. Second, the legal uncertainty about who is the true owner of the properties makes it less likely that foreigners will invest there, which again reduces property prices. ${ }^{56}$ It is for this reason that when GC applicants were submitting estimations of the value of their properties to the ECtHR, they compared them with similar properties in the south, rather than the north, of Cyprus. ${ }^{57}$ Conversely, TC argue that the market price is simply the amount for which a property can be sold today. Thus, the only relevant market in this equation should be the one that exists in the north. It is this latter approach that has been adopted both by the IPC and the ECtHR. As the Court put it in Loizidou, '[t]he applicant was entitled to be fully compensated for loss of access to and control of her property but not for the diminished value of that property due to the general political situation. ${ }^{58}$

Leaving aside disagreements of principle, the best way to assess the adequacy of the IPC's awards is to compare them with those of the ECtHR. This becomes possible due to a series of cases whose merits the ECtHR decided before, but whose just satisfaction it decided after, Demopoulos. ${ }^{59}$ In those cases, Turkey argued that since the IPC was considered by the Court to be an effective remedy, it - rather than the ECtHR - should compensate the applicants. As part of its submissions to the Court therefore, Turkey included a list of the compensation amounts that the IPC would have provided to each applicant. The Court rejected the submission and awarded its own damages, thus providing a useful comparison between the amount asked

\footnotetext{
${ }^{53}$ Hentrich v. France (Application no. 13616/88) (1994) 18 E.H.R.R. 440, para 42.

${ }^{54} 154$ out of 935 cases submitted to the IPC have been revoked to date. (Note 41 above, p 5.)

${ }^{55}$ For a theoretical discussion of this debate, see note 24 above, $\mathrm{p} 333$.

56 The uncertainty of 'TRNC' titles was confirmed by the decision of the Court of Justice of the European Union in Apostolides v Orams, C-420/07, EU:C:2009:271.

${ }^{57}$ Strati v. Turkey (Application no. 16082/90) (2010), para 31.

${ }^{58}$ Loizidou v. Turkey (Just Satisfaction) (Application no. 15318/89) (1998) 26 E.H.R.R. CD 5, para 30.

${ }^{59}$ See, for example, note 57 above.
} 
by the applicant, that offered by the IPC and that which was ultimately ordered by the ECtHR. ${ }^{60}$ The numbers suggest that what the applicants were asking for and what the IPC was providing were indeed worlds apart. ${ }^{61}$ The Court has tried to navigate the middle ground between the two sides by pointing out on the one hand that the GC claims were exaggerated, but finding on the other that the IPC's suggested amounts did not compensate the applicants to a sufficient degree. ${ }^{62}$ Ultimately however, the compensation award ordered by the ECtHR was closer to the amount offered by the IPC rather than that requested by the applicants. ${ }^{63}$

The human rights compatibility of this remedy is further supported by the Court's longstanding practice of giving States a wide margin of appreciation and allowing them to determine what is a fair compensation amount. ${ }^{64}$ The ECtHR has therefore held that although some compensation has to be paid to the applicants, this does not have to be the full market price of the property. ${ }^{65}$ In fact, the Court's previous case law suggests that under specific conditions, the margin of appreciation becomes even wider. Such conditions include the existence of transitional situations resulting in 'a wide-reaching but controversial legislative scheme with significant economic impact for the country as a whole ${ }^{66}$ and the exceptional context of the German reunification. ${ }^{67}$ Arguably the context in Cyprus and other societies divided by frozen conflicts, whereby potentially thousands of applicants will be remedied for their displacement, also amounts to such an exceptional situation. Therefore, despite complaints that the Commission is compensating applicants with a lower award than what they would have received at the ECtHR, or than the amount they would have secured had they sold their property themselves, this is unlikely to constitute a violation of the right. It is worth noting however, that the margin of appreciation in such cases is so wide because the IPC is only remedying violations of the right to property; had it also been remedying applicants for violations of the right to home, the margin would have been much narrower. ${ }^{68}$

Nevertheless, even if the compensation amount itself does not need to be increased, it would be better in terms of the trust-building objectives of the Commission, if it justified its decisions about the value of the award. Although the ECtHR did not make any reference to the Pinheiro Principles in its Cyprus judgments, it noted in Chiragov and Sargsyan that institutions remedying forced displacement should be in line with international best practices. ${ }^{69}$ One way of achieving this is by enhancing the transparency of the remedying body by offering an explanation for the compensation amount that each applicant has received. ${ }^{70}$ For instance, when

\footnotetext{
${ }^{60}$ However, even this is not a perfect comparison because the applicant requested and the Court awarded compensation for the loss of use of the property, while the IPC's amount reflected the compensation for both the loss of use and the property itself.

${ }^{61}$ For example, in Strati the applicant requested EUR 438,710 and the IPC offered EUR 34,531 (See note 57 above, para 34). Interviewees suggest that the compensation amounts awarded by the Commission have been reduced considerably since then.

62 Ibid., para 34.

${ }^{63}$ Ibid., para 34.

${ }^{64}$ This was expressed in the clearest terms in Lithgow and Others v. United Kingdom (Application no. 9006/80) (1986) 8 E.H.R.R. 329, para 122, where it was held that ' $[\mathrm{t}]$ he Court's power of review in the present case is limited to ascertaining whether the decision regarding compensation fell outside the United Kingdom's wide margin of appreciation; it will respect the legislature's judgement in this connection unless that judgment was manifestly without reasonable foundation.'

${ }^{65}$ Holy Monasteries v. Greece (Application no. 13092/87) (1995) 20 E.H.R.R. 1, para 71.

${ }^{66}$ Broniowski v. Poland (Application no. 31443/96) (2005) 40 E.H.R.R. 21, para 182.

${ }^{67}$ Von Maltzan and Others v. Germany (Application no. 71916/01) (2006) 42 E.H.R.R. SE11, para 77.

${ }^{68}$ See Paraskeva and Meleagrou at note 37 above, p 848.

${ }^{69}$ See note 2, para 238 and note 4, para 199.

${ }^{70}$ See note 15 above, para 12.1 .
} 
the IPC compensates an applicant, s/he receives a lump sum of money, which covers both the loss of use and the loss of the property itself, without any explanation of how that amount was calculated. ${ }^{71}$ It would have been better for the Commission, or any other body with a similar mandate, to split the award into two and list the factors that it took into account when deciding each of the amounts. Ideally, the remedying body's reasoning and key conclusions in each case should be made publically available in order to provide guidance to future applicants as to what they should expect from the application process. Taking such a step increases the transparency of the whole process and avoids legal challenges about the effectiveness of the remedying body. At the same time, a reasoned decision shows to displaced persons that the remedying body has seriously considered their arguments and that the final outcome of their case is a welljustified one, thus helping them better understand and accept the remedy they have been granted. ${ }^{72}$ This is particularly important in post- or frozen conflict contexts where the remedying body is likely to be providing compensation amounts that fall below the market price and might therefore be unpopular with the applicants. It is presumably because of these policy reasons that the ECtHR has held that any judicial decisions affecting property rights should adequately state the reasons on which they are based. ${ }^{73}$

\section{B. The remedy of exchange}

The second remedy that the IPC can provide is exchange, which allows the applicant to trade the property s/he was displaced from in the north with TC land of equal value in the south of the island. This remedy is made possible due to a combination of 'TRNC' constitutional provisions and the ('TRNC') İTEM Law. ${ }^{74}$ On the one hand, Article 159 of the 'TRNC' Constitution provides that any land that was abandoned in 1974 became property of the 'TRNC', which it can use as it sees fit. ${ }^{75}$ On the other, the ITEM Law gives displaced TC the opportunity to exchange their properties, which are in the south, GC-controlled part, of the island, with properties acquired by the 'TRNC' under Article 159. ${ }^{76}$ Most TC have made use of this provision, which means that, under 'TRNC' law, TC land in the south belongs to the 'TRNC', and not the displaced TC themselves. It is these provisions that Section 8(5) of Law $67 / 2005$ relies on in order to make the remedy available to the applicants. Exchange has been accepted as an effective remedy in Xenides-Arestis, Demopoulos and Eugenia Michaelidou Developments Ltd and Michael Tymvios v. Turkey. ${ }^{77}$ Nevertheless, the serious practical problems this remedy has posed in terms of its implementation, suggest that it would be better if the IPC, and other remedying bodies in similar contexts, did not make it available to applicants at all. Notably, these problems stem from the ECtHR's unwillingness in Demopoulos to engage in a serious discussion about the legality and legitimacy of the IPC and

\footnotetext{
${ }^{71}$ Information obtained through the interviews. This is despite the fact that Section 7(5) of the Rules of Law $67 / 2005$ provides that '[t]he Commission shall, after hearing all the views and claims of the parties, announce its reasoned decision within three months.'

${ }^{72}$ This argument has been made in the South African displacement context, but equally applies to frozen conflicts. (A Bohlin, 'A Price on the Past: Cash as Compensation in South African Land Restitution' (2004) 38(3) Canadian Journal of African Studies 672.)

${ }^{73}$ Kushoglu v. Bulgaria (Application no. 48191/99) (2007), para 52.

74 ('TRNC') Law No. 41/1977 (Settlement, Land Distribution, and Equivalent Property (ITEM) Law).

75 Constitution of the 'TRNC', adopted on 5 May 1985.

${ }^{76}$ A Gürel, 'Displacement in Cyprus: Consequences of Civil and Military Strife (Report 4 - Turkish Cypriot Legal Framework)' (Nicosia: Peace Research Institute Oslo, 2012), pp 23-26.

${ }^{77}$ Eugenia Michaelidou Developments Ltd and Michael Tymvios v. Turkey (Application no. 16163/90) (2004) 39 E.H.R.R. 36 .
} 
the 'TRNC' more generally; had this taken place, the problems associated with the remedy of exchange could have been avoided. ${ }^{78}$

The first problem is most vividly illustrated through the ECtHR case of Tymvios, where the applicant reached a friendly settlement with the IPC for the exchange of his property. According to Section 8(5) of Law 67/2005, the exchange happens between the applicant's land and 'property which is proposed to the applicant' by the IPC; in this case, the Commission's proposal, which was accepted by the applicant, concerned two plots of land in the areas under the effective control of the RoC on which schools had been built. ${ }^{79}$ When the applicant tried to enforce the IPC's decision by asking the RoC Land Registry to transfer the two schools in his name, the Republic refused. Soon after however, the ECtHR approved the friendly settlement that had been reached between the applicant and the IPC and which the RoC had refused to recognise. ${ }^{80}$ This left the RoC with little choice but to buy off the land from the applicant (for $€ 13$ million) in order to ensure the ongoing operation of the schools. ${ }^{81}$ The problem with the remedy of exchange therefore, lies with the fact that it is provided by Turkey, but the state that is most directly and detrimentally affected by it is Cyprus. Yet, there is no mechanism - and no political willingness on either of the two sides - for the latter to be consulted in the decisionmaking process leading to the award of this remedy. Tymvios not only highlighted to GC the practical difficulties entailed in the remedy of exchange, but also raised questions about what motivated the IPC to choose these two plots of land in the first place; neither of the two considerations contributed to the betterment of inter-ethnic relations on the island.

The second, and more fundamental problem with this remedy is its lack of principle, which can lead to contradictory decisions about who is entitled to what. The ECtHR has already held in Kazali v. Cyprus that TC properties in the areas controlled by the RoC belong to the TC themselves, not the 'TRNC' ${ }^{82}$ Accordingly, these properties fall under (RoC) Law 139/1991, which makes the RoC Minister of Interior responsible for their protection and authorises him to exercise control over them until the Cyprus problem has been resolved. In Kazali, and making no reference to Demopoulos that had been decided 2 years before, the ECtHR endorsed recent amendments to Law 139/1991, which allow TC to acquire control of their properties from the RoC Minister of Interior even before the Cyprus problem is resolved. Therefore, the same plots of land are subject to two property regimes: on the one hand, Demopoulos is based on the presumption that they belong to the 'TRNC', which can exchange them as it sees fit and on the other, Kazali confirms that the true owner of the properties remains the TC individual. This means that, because of the remedy of exchange, TC properties in the south might in the future, be subject to contradictory legal provisions, both of which, the ECtHR has endorsed.

These problems suggest that when designing such institutions, policy makers should seriously consider the types of remedies that could be made available to the applicants and exclude those that are likely to create additional friction between the different communities. Significantly, the danger of the remedy of exchange resulting in a property being subject to multiple claims and conflicting legal obligations does not only arise in the case of Cyprus; rather, it can be a

\footnotetext{
${ }^{78}$ See notes 38-40 above and accompanying discussion in the main text.

79 According to the RoC, a TC individual (and not the 'TRNC') owned the land in question; this land was expropriated by the RoC in order to build the two schools.

${ }^{80}$ See note 77 above.

${ }^{81}$ S Evripidou, 'Government approves first ever land swap deal' (Cyprus Property News, 10/07/2012), available at http://www.news.cyprus-property-buyers.com/2012/07/10/first-ever-land-swap-deal-approved/id=0012112 [last accessed 17 June 2016].

${ }^{82}$ Kazali v. Cyprus (Application no. 49247/08) (2012).
} 
common phenomenon in frozen conflicts. Since the individual complaints mechanism only allows the ECtHR to address and create legal obligations for one state at a time, the remedies provided by a respondent state on one side of the disputed border, do not have to be compatible with (or even take into account) the remedies that are granted on the other. This is confirmed by the Concurring Opinion of Judge Ziemele in Sargsyan, who noted that 'The two States do not need to agree on [... the provision of remedies] together. By virtue of their Convention obligations, they could propose unilateral solutions for these people. ${ }^{83}$ Therefore, if Armenia and Azerbaijan unilaterally provide the remedy of exchange, as Turkey does in Cyprus, a single property might legitimately be claimed by different displaced people. When the remedying bodies respond to these claims, they might be perceived as acting with a political agenda and suffering from a lack of independence. Thus, careful planning and even some rudimentary cooperation between respondent states before the establishment of such institutions could bolster their real and perceived impartiality and contribute to the objectives of transitional justice.

\section{The remedy of restitution}

The final remedy that the IPC provides, and the one preferred by the majority of GC, is restitution. ${ }^{84}$ Nevertheless, the IPC has, so far, awarded restitution, in only 8 cases, a fact that is at least partly due to the strict legal requirements that the remedy is subject to. ${ }^{85}$ Under Law $67 / 2005$, restitution only becomes available when the property in question has not been transferred to any natural or legal person; it has not been allocated for public interest reasons; its location and physical condition do not endanger national security and public order; and it is outside any military areas. ${ }^{86}$ However, some of these obstacles are particularly difficult to overcome. For example, due to the implementation of the ('TRNC') İTEM Law, whose explicit purpose was to distribute GC properties to TC beneficiaries, most land has already been transferred to natural or legal persons.

On the one hand, an argument could be made that a restrictive approach to restitution is legally acceptable. This is supported by ECtHR statements in Demopoulos that the choice of remedy falls within the discretion of each respondent state since 'from a Convention perspective, property is a material commodity which can be valued and compensated for in monetary terms. ${ }^{87}$ On the other, the tratement of the applicants' homes as just another piece of property, which could be bought off, only became possible through the Court's dubious reasoning in Demopoulos that the passage of time since their displacement, even if this was due to delays by the respondent state to provide a remedy, could extinguish rights protected under Article 8 . Moreover, the Pinheiro Principles require that compensation should only be provided when it is 'factually impossible' to return property. ${ }^{88}$ Further support for this position was, rather confusingly, offered in the case of Xenides-Arestis, in which the ECtHR held that the original provisions of the IPC Law did not provide an effective remedy because they did not allow for restitution under any circumstances. While it is not clear whether a restrictive approach to restitution is legally problematic, it certainly has had serious detrimental effects on the trust levels of GC towards TC institutions. GC have historically preferred the remedy of restitution,

\footnotetext{
${ }^{83}$ See note 2 above, Concurring Opinion of Judge Ziemele, para 7.

${ }^{84}$ D Beyatll, K Papadopoulou and E Kaymak, 'Solving the Cyprus Problem: Hopes and Fears' (Nicosia: Interpeace/Cyprus 2015 Initiative, 2011), p 110.

${ }^{85}$ See note 41 above.

${ }^{86}$ Law 67/2005, Section 8(1).

${ }^{87}$ See note 3 above, para 115 .

${ }^{88}$ See note 15 above, Principle 2.1.
} 
but TC have considered compensation to be the best remedy to the displacement problem. ${ }^{89}$ Considering that Law 67/2005 is essentially allowing the TC political elites to address the displacement problem almost exclusively through their preferred remedy, this creates disincentives for the negotiation of a political settlement that will require that at least some land be returned back to the GC. In light of the conflicting legal obligations and the undermining of transitional justice objectives if the remedying body adopts an excessively restrictive approach, policy makers in frozen conflicts are advised to make restitution available at least to some categories of applicants.

Moreover, they should ensure that if restitution is an available remedy in the Law, it should also be provided in practice. This is not what has happened in the case of Cyprus, where the way in which the provisions of Law 67/2005 have been applied (or rather, not applied) to the Varosha cases raises the most serious concerns about violations of the rights to property and fair trial. Varosha, situated in the non-RoC controlled part of the island, is a ghost town. GC who were living there fled the area in 1974, but TC have not been allowed to occupy their properties. Rather, the town was fenced off and has remained empty and unused since then. The properties found in this area therefore, are ideal for restitution, a fact that was also recognised by the UN Security Council, which has called for the return of Varosha to its lawful owners under UN administration. ${ }^{90}$ Yet, the IPC has, so far, not remedied - through restitution or otherwise - any land in Varosha. Although the Commission tends to deal with its cases in a loose chronological order, the Varosha cases have been left at the back of the queue. ${ }^{91}$ Lawyers appearing before the IPC have complained that if a case concerns several plots of land, some of which are located in Varosha and others elsewhere, it will remain stagnant until the claim relating to Varosha is removed from it. ${ }^{92}$ Since the Law includes no exceptions about the special treatment of Varosha cases, this differentiation in how the IPC deals with them compared to the rest is completely arbitrary. ${ }^{93}$

The most plausible explanation for this is that the Varosha cases are politically controversial and are therefore, better left undisturbed. However, the IPC is a legal, not a political body and, legally speaking, there is nothing complicated about these properties. ${ }^{94}$ Thus, the refusal of the IPC to even hear, let alone decide the Varosha cases is in all likelihood a violation of the right to fair trial, protected under Article 6 of the Convention and in particular, the principle of access to justice. As the Court put it in Golder v. UK, '[t] he fair, public and expeditious characteristics of judicial proceedings are of no value at all if there are no judicial proceedings. ${ }^{95}$ Moreover, this possibly constitutes a violation of Article 1-1 since it involves a situation where the applicant is being deprived of his/her property, yet the State is refusing to remedy him/her in any way. ${ }^{96}$ Equally problematic to the legal issues that arise from the treatment of the Varosha

\footnotetext{
${ }^{89} \mathrm{~K}$ Özersay and A Gürel, 'Property and Human Rights in Cyprus: The European Court of Human Rights as a Platform of Political Struggle’ (2008) 44 Middle Eastern Studies 291.

${ }^{90}$ UN Security Council Resolution 550 (11 May 1984), Article 5.

${ }^{91}$ Information obtained through the interviews.

92 Ibid.

${ }^{93}$ Law 67/2007, Sections 4(1) and (2) respectively simply refer to 'all natural or legal persons claiming rights to movable and immovable properties [...] abandoned in the North prior to 13 February 1975' and include no exceptions.

${ }^{94}$ This is another example of how more theoretical arguments relating to the legality and legitimacy of the IPC, which the ECtHR refused to entertain in Demopoulos, can have an impact on the practical effectiveness of the remedies provided by the Commission. (See notes 38-40 above.)

${ }^{95}$ Golder v. United Kingdom (Application no. 4451/70) (1979-80) 1 E.H.R.R. 524, para 35. See, also, Ashingdane v. United Kingdom (Application no. 8225/78) (1985) 7 E.H.R.R. 528, para 57.

96 This was, after all, the very basis of the Court's reasoning in Loizidou.
} 
cases is the effect that this has on trust-building between the two communities. In particular, it raises questions among GC about the good faith of the IPC since it is refusing to hear those cases that are most likely to result in the granting of the applicants' preferred remedies.

\section{A PROCEDURAL ASSESSMENT OF THE IPC}

\section{A. The lack of legal clarity in the process}

Equally important to the provision of satisfactory remedies is ensuring that the Commission complies with clear and transparent rules of procedure. Law 67/2005 includes detailed provisions about the process one has to follow in order to be remedied by the IPC. Initially, the applicant must satisfy the Commission that he was either registered in 1974 in the RoC Land Registry as the owner of the property or that he is the legal heir of such a person. ${ }^{97}$ Then, according to the Law, the application follows a procedure resembling that of a normal civil case. ${ }^{98}$ The two parties - the applicant and a lawyer from the 'TRNC' Attorney-General's Office $^{99}$ - submit their arguments and ' $[\mathrm{t}]$ he Commission, after having heard the arguments of the parties and witnesses, and having examined the documents submitted', decides on the appropriate remedy. ${ }^{100}$ However, in practice, a hearing stage where the applicants formally present their arguments is only available in exceptional circumstances; so far, only 21 cases have followed the procedure described in Law 67/2005. ${ }^{101}$

In the remaining 878 cases, the parties follow a long - and largely undocumented, but standard - procedure that is designed to lead to a friendly settlement. ${ }^{102}$ First, the applicant submits his/her documentation and provides evidence that $\mathrm{s} / \mathrm{he}$ is the owner or heir of the property. ${ }^{103}$ If the IPC is satisfied with this documentation, it gives a date for a 'mention meeting', which is where the friendly settlement takes place. ${ }^{104}$ During this meeting, the lawyer from the 'TRNC' Attorney-General's Office recommends the remedy of compensation and, based on an evaluation by the 'TRNC' Land Registry, makes an offer. The applicant is likely to make a counter-offer and a negotiation, which is overseen by three members of the IPC, takes place. If the two sides fail to agree on a negotiated amount, they can meet again in subsequent mention meetings until they reach a friendly settlement. If this proves unobtainable, the applicant can withdraw his/her application or ask that it proceeds to a hearing. ${ }^{105}$ In case a hearing takes place, the applicant can appeal the IPC's decision to the 'TRNC' High Administrative Court. ${ }^{106}$ Alternatively, if a friendly settlement is reached, the applicant provides up-to-date evidence

\footnotetext{
${ }^{97}$ Law 67/2005, Section 6(2).

${ }^{98}$ Law 67/2005, Section 16 and the Rules of Law 67/2005, Sections 7 and 9.

${ }^{99}$ Law 67/2005, Section 7.

${ }^{100}$ Law 67/2005, Section 8.

${ }^{101}$ See note 41 above, p 5.

102 Ibid. Section 6 of the Rules of Law 67/2005 provides that 'the Ministry responsible for Housing Affairs shall prepare a draft friendly settlement agreement [...] and serve it to the applicant.' However, it gives no explanation on how this agreement is negotiated between the two parties.

${ }^{103}$ Rules of Law 67/2005, Section 6(1).

104 This whole process of the 'mention meetings' is not documented at all in the Law or the Rules. Information on this was obtained solely through the interviews.

105 Section 6(5) of the Rules of Law 67/2005. Note also that it is possible, but rare, for an applicant who refuses to go through the friendly settlement procedure to have the hearing instead. (See, for example, Andreas Lordos Estates Ltd v. Ministry Responsible for Housing Affairs (Supreme Court of the 'TRNC', C. 1/2014) and Eleni Meleagrou v. TRNC Attorney-General via Immovable Property Commission (High Administrative Court of the 'TRNC', C. 15/2011).)

${ }^{106}$ Law 67/2005, Section 9.
} 
that he is still the owner and approximately 12 months later, s/he signs the property away to the 'TRNC' and receives the compensation amount. ${ }^{107}$

It appears therefore that rather than the IPC operating as the final decision-maker in an adjudicative process, it is acting as the facilitator to a negotiation. The argument here is not that the hearing process described in the Law is necessarily better than the method of negotiation followed in practice. Adjudication might be more transparent, but a negotiated outcome is speedier, less confrontational and more likely to be accepted by the applicants than an imposed judicial decision. Ultimately however, whether the remedy will be provided through a hearing or something less formal, this should be fully reflected in the law. A disparity between the legal text and what is happening on the ground results in a lack of clarity and certainty of the process, and in turn, to potential human rights violations. In particular, Article 1-1 of the European Convention requires that any interferences with the right to property are 'provided by law'. Interpreting this requirement in light of the rule of law, ${ }^{108}$ the Court has demanded not only that the interference with the right to property has a basis in national law, but also that this law is accessible, precise and foreseeable. ${ }^{109}$ It has, for example, found a violation of Article 1-1 in cases where there were inconsistencies in the process described in the law, a situation that resembles what is being described here. ${ }^{110}$

In addition to complying with its human rights obligations, a respondent state should make sure that the process followed by the remedying body is transparent for three additional reasons. First, the Pinheiro Principles have emphasized the need to ensure that the remedying process is as certain and transparent as possible. ${ }^{111}$ Second, following a clearly defined procedure is important for all state institutions, but it is especially so for bodies such as the IPC, which were created precisely in order to remedy human rights violations. ${ }^{112}$ Finally, if the remedying body is following a more transparent process, this can affect the displaced population's perceptions about the fairness, neutrality and legitimacy of the other community's institutions. In turn, such perceptions can have a positive impact on the extent to which the applicants feel truly remedied and can, therefore, influence their willingness to coexist and cooperate with members of the other community in the future. ${ }^{113}$

Related to the requirement of transparency is the notion of independence. One important way in which the 'independence, impartiality and expertise' of the remedying body can be secured is 'through appropriate rules on [its] composition that may provide for the inclusion of international members. ${ }^{, 14}$ The importance of the composition of the remedying body was also emphasised in Xenides-Arestis, in which the ECtHR ruled that the Commission should comprise of international, in addition to the existing TC, members. ${ }^{115}$ In an attempt to comply

\footnotetext{
${ }^{107}$ Information obtained through the interviews.

${ }^{108}$ Iatrides v. Greece (Application no. 31107/96) (2000) 30 E.H.R.R. 97, para 58.

${ }^{109}$ Carbonara and Ventura v. Italy (Application no. 24638/94) (2000), para 64; Beyeler v. Italy (Application no. 33202/96) (2001) 33 E.H.R.R. 52, para 109.

${ }^{110}$ Baklanov v. Russia (Application no. 68443/01) (2005), para 46.

111 See note 15 above, Principle 12.1.

112 E Brems and L Lavrysen, 'Procedural Justice in Human Rights Adjudication: The European Court of Human Rights’ (2013) 35 Human Rights Quarterly 176, p 185.

${ }^{113}$ A similar point was made when assessing the practices of the South African Commission on Restitution of Land Rights. (T Roux, 'Land Restitution and Reconciliation in South Africa', in F Du Bois and A Du Bois-Pedain (eds), Justice and Reconciliation in Post-Apartheid South Africa (CUP, 2008).)

${ }^{114}$ Council of Europe Parliamentary Assembly, 'Solving Property Issues of Refugees and Internally Displaced Persons' (Resolution 1708 (2010)), para 10.7.

115 See note 35 above.
} 
with this requirement, Turkey amended the original provisions of Law 67/2005 to provide that the IPC should consist of 5 to 7 members, at least 2 of whom are not Cypriots, Greeks or Turks, ${ }^{116}$ a change which the ECtHR applauded in Demopoulos. ${ }^{117}$ Nevertheless, it appears that the two international members, who played such an important role in rendering the IPC an effective organ in the eyes of the ECtHR, are rarely actually present. The Law states that the Commission can convene when there is a two-thirds majority, yet makes no provision for the compulsory presence of at least one of the international members. ${ }^{118}$ As a result, the international members tend to sit with the Commission only when there is a hearing, rather than also participate in the friendly settlement proceedings. ${ }^{119}$ Considering the rarity of the hearings, most applicants never have any contact with the international members at all. Drawing lessons from the Cypriot experience therefore, policy makers in frozen conflicts should be careful to not only ensure the involvement of international members on paper, but also guarantee that their actual participation is both meaningful and regular.

\section{B. Delays in the proceedings of the IPC}

The final procedural flaw that can undermine trust-building among the different parties and result in human rights violations is an unreasonable delay in proceedings. This has been a problem for the IPC, which takes approximately 7-8 years to finalise a case that is resolved through negotiations, includes no hearing by the Commission itself and no appeal to the 'TRNC' Courts. ${ }^{120}$ The ECtHR held in Meleagrou v. Turkey that the IPC is a body that should comply with Article 6 requirements, including that of providing timely access to a judicial body. ${ }^{121}$ While the Court has not indicated a specific time frame after which Article 6 will have been violated, factors that affect the reasonableness of the delay include the complexity of the case, the applicant's and the relevant authorities' conduct and what was at stake in the dispute. ${ }^{122}$ IPC cases are relatively simple since all that is required is to prove ownership of the property by presenting the relevant title deeds, yet at the same time, what is at stake for the applicant is extremely important. Moreover, while the Commission has over the years been manned adequately with administrative staff and translators, the Attorney-General's Office and the Land Registry, on which the remedying process also relies, have not. It is for example, a frequent phenomenon for applicants to appear at the IPC for scheduled mention meetings, only to be told by the administrative staff that the valuation by the Land Registry has not been completed yet or that the lawyer from the Attorney-General's Office will not be appearing that day. ${ }^{123}$ Although these are not judicial organs, their delays can still cause a violation of Article 6 since according to the ECtHR's jurisprudence, the respondent state is responsible for the actions of all public institutions. ${ }^{124}$ Moreover, while it is appreciated that the delays are due to these bodies' excessive workload, this is not an excuse that the ECtHR has been willing to

\footnotetext{
${ }^{116}$ Law 67/2005, Section 11(1).

${ }^{117}$ See note 3 above, paras 76-77.

${ }^{118}$ Law 67/2005, Section 11(2).

${ }^{119}$ Information obtained through the interviews.

${ }^{120}$ Ibid. If a hearing takes place, the process can take significantly longer (see, for example, Andreas Lordos in note 105 above).

${ }^{121}$ Meleagrou v. Turkey (Application no. 14434/09) (2013), para 17.

${ }^{122}$ Frydlender v. France (Application no. 30979/96) (2001) 31 E.H.R.R. 52, para 43. Exessive delays in the process can also result in violations of the right to an effective remedy, under Article 13 of the European Convention (Kudła v. Poland (Application no. 30210/96) (2002) 35 E.H.R.R. 11.)

${ }^{123}$ Information obtained through the interviews.

${ }^{124}$ Martins Moreira v. Portugal (Application no. 11371/85) (1991) 13 E.H.R.R. 517, para 60.
} 
entertain, since it has held in the past that it 'is for the Contracting States to organise their legal systems in such a way' as to meet their Article 6 obligations. ${ }^{125}$

Such delays are not only problematic in terms of Turkey's ECtHR obligations, but can also fuel negative perceptions about the IPC's neutrality, since they are often perceived as evidence of the institution's bad faith towards GC applicants. It is presumably for this reason that one of the most oft-repeated guidelines found in international standards is that remedying institutions should act in a 'timely' manner and adopt 'expedited procedures'. ${ }^{126}$ Illustrating the detrimental effects of these delays to the trust-building process, are the views of GC lawyers, which they potentially also shared with their clients, that the IPC's delays are caused on purpose. ${ }^{127}$ Allegedly, this is done so that the applicants 'break' and agree to a lower compensation amount, are discouraged from asking for restitution and do not even consider challenging the IPC's decision in the High Administrative Court. Such negative depictions of TC bodies, whether true or not, feed into the already prevalent culture of mistrust of the GC community and make it more difficult for its members to perceive the IPC as legitimate and impartial. This, not only deters people from applying to the Commission, but also undermines the prospects of reaching a comprehensive political settlement to the Cyprus problem.

At least some of the accusations of the IPC's bad faith are triggered, albeit unintentionally, by the IPC itself, whose strict adherence to the letter of the law often causes further delays to the proceedings of a case. An example of this concerns the obligation to provide written evidence of the applicant's name and identity before a date for the first mention meeting is scheduled. Often however, and particularly because official documents were lost during the war and had to be replaced, there might be a discrepancy in the spelling of the applicant's name between different official registers. Rather than accepting such variations as inevitable characteristics of Cypriot records and focusing on the substance of the case, the IPC requires that the applicant provides further evidence proving - beyond any reasonable doubt, rather than on the balance of probabilities - that $\mathrm{s} / \mathrm{he}$ is indeed the person s/he claims to be. ${ }^{128}$ Particularly striking is one TC lawyer's complaint that the IPC postponed the first mention meeting of a case 28 times due to minor misspellings in the applicant's name or other cosmetic changes in his application. According to the same interviewee, this attention to detail and rigid compliance with procedural requirements is a characteristic only of the IPC and not of TC courts more generally.

In order to address the delays of the IPC therefore, and avoid both the findings of human rights violations and the undermining of transitional justice objectives, two steps can be adopted. On the one hand, it is necessary to adequately staff both the remedying body itself, but also other governmental departments that are instrumental to the process, such as the Land Registry and the Attorney-General's Office. If such ancillary departments employ personnel that is exclusively tasked with working on the remedying process, this will drastically reduce the waiting time for each application and help build much-needed expertise among state officials. On the other hand, it would be to the overall benefit of the process if the evidentiary standards that applicants have to comply with were somewhat more relaxed. This suggestion was endorsed both by the Parliamentary Assembly ${ }^{129}$ and the European Court itself when it ruled

\footnotetext{
${ }^{125}$ Vocaturo v. Italy (Application no. 11891/85) (1991), para 17.

${ }^{126}$ See note 114 above, paras 10.1 and 10.6 respectively.

${ }^{127}$ Information obtained through the interviews.

${ }^{128}$ Law 67/2005, Section 6(2).

${ }^{129}$ See note 114 above, para 10.6 .
} 
in Chiragov/Sargsyan that the respondent states establish mechanisms that are 'easily accessible and provide procedures operating with flexible evidentiary standards. ${ }^{2130}$

\section{CONCLUSION}

The most direct contribution that an assessment of the IPC could make is provide insights to those interested in remedying forced displacement in Cyprus itself. On the one hand, the IPC could be used as a blueprint for the creation of a remedying body after a comprehensive settlement to the Cyprus problem has been agreed. Since it is only serving a temporary function, ${ }^{131}$ the Commission is likely, following a peace agreement between the two sides, to be replaced by an institution tasked with permanently remedying both Greek and Turkish Cypriots. ${ }^{132}$ When designing such an institution, lessons from the IPC could point to what should be adopted and what is best avoided. At the same time however, the very existence of the IPC makes the work of this future institution more difficult because it will have to determine how to handle the properties of those displaced GC who have already been remedied by the Commission, a task that becomes especially daunting in cases of exchange. ${ }^{133}$ On the other hand, a better understanding of the Commission's outcomes and procedures could lead to their improvement until such a settlement is reached. While following Demopoulos the IPC is considered as providing an effective remedy, GC are likely to challenge this ruling and argue that the Commission's practices result in violations of the rights to property and fair trial. ${ }^{134}$ In such a case, a clear picture of how the IPC operates and what exactly it delivers will form the backbone of the applicants' arguments and the debate that will follow.

So far, an assessment of the IPC suggests that its practical impact in Cyprus has not always been positive. Anecdotal evidence indicates that flaws both with the Commission's procedures and the substantive remedies it provides, which are likely to result in findings of human rights violations, have been perceived by the applicants and the GC society at large as evidence of bad faith by Turkey and the 'TRNC'. In turn, this fuels the GC population's existing distrust of the TC community, its leadership and institutions and undermines the likelihood of the IPC contributing to a thawing of the frozen conflict. At the same time however, the establishment of the Commission can also teach (Greek) Cypriots important lessons. It can send them the message that they have to speed up and conclude the political negotiations to the Cyprus problem before the displacement issue is resolved through a mechanism they consider inadequate. The ECtHR's endorsement of the IPC in Demopoulos has also conveyed to GC that a remedy for their displacement will in all likelihood not entail full restitution of their property rights; their gradual recognition of this makes it more likely that they will more easily accept the remedying provisions of the comprehensive peace agreement. Furthermore, the

\footnotetext{
${ }^{130}$ See note 2, para 238 and note 4, para 199.

${ }^{131}$ Cyprus v. Turkey (Just Satisfaction) (Application no. 25781/94) (2014) 59 E.H.R.R. 16, para 63.

132 This is the arrangement that was proposed in the Annan Plan. (The Comprehensive Settlement for the Cyprus Problem (31/03/2004), Annex IIV, Attachment 2). Matson (note 14 above) makes a variation of this argument by contending that the IPC could provide guidance for the establishment of a bi-communal remedying body before the reaching of the comprehensive peace settlement. While this is an interesting suggestion, it leaves unanswered questions that go to the heart of the conflict, such as who is going to finance the compensation awards ordered by this body.

${ }^{133}$ I would like to thank Dr. Nikolas Kyriakou for pointing this out to me.

134 The possibility of such cases reaching the ECtHR in the near future has already been reported in the Cypriot media. See, for example, Politis, 'Property Issue at the ECHR again' (11 December 2015), available at http://m.politis-news.com/cgibin/hweb?-A=309748\&-V=articles [last accessed 17 June 2016, author's translation].
} 
friendly settlement procedure, despite its many problems, has confirmed that when remedying applicants, there is an alternative to litigation, which, if implemented correctly, could work very well.

In addition to being valuable to Cypriot peacebuilders, an assessment of the IPC could provide useful lessons about the remedying of displaced people in other frozen conflicts as well. Even though there are international standards that provide some guidance about the establishment of such remedying bodies, both they and the pronouncements of the ECtHR on this issue remain rather general and vague. Conversely, examining the experiences of a remedying body in practice can provide more detailed insights on how similar institutions in other contexts can be improved. In Europe alone, the lessons drawn from the experiences of the IPC could have practical implications in South Ossetia, Abkhazia, Transnistria, Eastern Ukraine and NagornoKarabakh. ${ }^{135}$ While there have been no ECtHR cases concerning forced displacement in the first three regions, the context of these conflicts is similar enough to Cyprus to raise expectations that if an application is submitted, it will be dealt with in an analogous way. ${ }^{136}$ Moreover, the conflict in Eastern Ukraine has given rise to an inter-state case and approximately 1,600 individual applications to the ECtHR concerning alleged violations of property rights, which are also likely to be decided in a similar manner to Loizidou. ${ }^{137}$ Most urgently however, a comparative analysis of the IPC is particularly useful to the governments of Armenia and Azerbaijan, which are expected to set up 'a property claims mechanism [...] allowing the applicants and others in their situation to have their property rights restored and to obtain compensation for the loss of their enjoyment. ${ }^{138}$ While a comparison between Cyprus and the ex-Soviet regions is not always straight-forward, if this is done carefully, it could provide valuable sources of inspiration for solutions to their common problems.

In particular, in light of the twin objectives that a remedying body should satisfy - complying with human rights and helping build trust between the previously warring parties peacebuilders in different frozen conflicts should consider carefully the remedies that will be made available to the applicants. More specifically, there are practical and principled reasons why the remedy of exchange should be avoided altogether, while the remedy of restitution should become more readily available. Moreover, since compensation will probably be the most popular remedy, it is important that the award reflects, at least to some extent, the market value of the property. This award should also be accompanied in each case with an explanation of how it was calculated, a step that could increase levels of trust and acceptance of the remedying body's decisions among the displaced population. Equally important is the attention that should be paid to the procedures followed by the remedying bodies. In particular, the law should accurately reflect the process through which the applicants are remedied in practice and make provisions for the regular and meaningful participation of international members in the decision-making process. Finally, practical steps should be taken to ensure the swift remedying of the applicants, both by adequately staffing relevant government departments and by adopting more flexible evidentiary standards. A remedying body that complies with these guidelines does not in itself comprehensively resolve the frozen conflict; it does however,

\footnotetext{
${ }^{135}$ As of 2009, there were approximately 2.5-2.8 million displaced people, scattered over 11 of the 47 member states of the Council of Europe. (See note 21 above, para 1 and 3.)

${ }^{136}$ See, Ilaşcu and Others v. Moldova and Russia (Application no. 48787/99) (2005) 40 E.H.R.R. 46, para 314, where it was held that Russia's military and economic control of Transnistria rendered it responsible for violations of Articles 3 and 5 that had been committed there.

${ }^{137}$ ECtHR, 'Press Country Profile: Ukraine' (Strasbourg: Council of Europe, 2016), p 8.

${ }^{138}$ See note 2 above, para 238 and note 4, para 199.
} 
indicate the existence of good faith that can make a peace agreement both possible and sustainable. 